\title{
Energy Resource of Charcoals Derived from Some Tropical Fruits Nuts Shells
}

\author{
Damgou Mani Kongnine ${ }^{a^{*}}$, Pali Kpeloua ${ }^{a}$ N'Gissa Attah ${ }^{b}$, Saboilliè Kombate ${ }^{b}$, \\ Essowè Mouzouc, Gnande Djetelia and Kossi Napo ${ }^{\mathrm{a}}$
}

aDépartement de Physique, Laboratoire sur l'Energie Solaire-Université de Lomé, TOGO

${ }^{b}$ Département de Physique, Laboratoire Matériaux, Energies Renouvelables et Environnement (LaMERE), TOGO

'Département de Physique, Laboratoire de Physique des Matériaux et des Composants à Semi-conducteurs, Université de Lomé, TOGO

\begin{abstract}
This work was focused on carbonizing four tropical fruits shells wastes such as: coconut shells (CS), palmyra shells (PS), doum palm shells (DPS), whole fruit of doum palm (WFDP) and teak wood (TW) used as control. The aim was to investigate the potential of those biochar to be used as an alternative energy source in replacement of charcoal. The raw biomasses samples were carbonized under the same conditions and some combustion characteristics of the obtained biochar such as lower calorific value, energy per unit volume associated to bulk density, ash content, moisture content and ash mineral content were investigated. The temperature in the furnace was estimated during carbonization process using a K-type thermocouple. The thermal profile of the studied raw biomasses reveals three phases of carbonization. The biochar yield drops significantly for all biomasses as the final maximum temperature increases. The average yields obtained ranged from $37.81 \%$ for palmyra shells to $27.57 \%$ for the doum palm shells. The highest yield achieved was $42.32 \%$ obtained at $280^{\circ} \mathrm{C}$ for palmyra shells, the lowest yield $(24.42 \%)$ was recorded at the highest maximum temperature of $590{ }^{\circ} \mathrm{C}$ for doum palm shells. The results of energy parameters of the studied biochar showed that coconut shells charcoal presented the highest lower calorific value (28.059 MJ.kg-1), followed by doum palm shells (26.929 MJ.kg-1) when, with 25.864 MJ.kg-1 whole fruit of doum palm charcoal showed the lowest lower calorific value. Similarly, with the highest bulk density of $0.625 \mathrm{~g} / \mathrm{cm}^{3}$ coconut shells charcoal presented the highest energy per unit volume $\left(17536.88 \mathrm{~J} / \mathrm{cm}^{3}\right)$, whereas with the lowest bulk density of $0.415 \mathrm{~g} / \mathrm{cm}^{3}$, whole fruit of doum palm charcoal presented the lowest energy per unit volume. The ash content analysis showed that whole fruit of doum palm had the highest ash content (18.75\%) and palmyra nut shells charcoal (8.42\%). Teak wood charcoal, took as control, has the highest lower calorific value $\left(32.163 \mathrm{MJ} . \mathrm{kg}^{-1}\right)$, less dense as coconut shell $\left(0.43 \mathrm{~g} / \mathrm{cm}^{3}\right)$, his energy per unit of volume is $13830.09 \mathrm{j} / \mathrm{cm}^{3}$ but the lowest value of as content $(2.90 \%)$. Among these biomasses charcoals, only whole fruit of doum palm charcoal ash showed a high chloride and sulfide content respectively $9.73 \%$ and $1.75 \%$ in weight. From these results, the produced charcoals could be used as alternative fuels except for whole fruits of doum palm charcoal which chloride and sulfide content were found high. C2020. CBIORE-IJRED. All rights reserved
\end{abstract}

Keywords: Biochar, Charcoal, Wood, Carbonization, Alternative Fuels, Lower calorific value, Energy per unit volume

Article History: Received: July 18, 2019; Revised: December 16, 2019; Accepted: December 28, 2019; Available online: February 15, 2020

How to Cite This Article: Kongnine, D.M., Kpelou, P., Attah, N., Kombate, S., Mouzou, E., Djeteli, G. and Napo, K. (2020) Energy Resource of Charcoals Derived from Some Tropical Fruits Nuts Shells. International Journal of Renewable Energy Development, 9(1), 29-35. https://doi.org/10.14710/ijred.9.1.29-35

\section{Introduction}

Wood energy, has been and remains today, undoubtedly the main source of primary energy used essentially for cooking in developing countries. Fire wood and wood charcoal are the main sources of energy supply for most of households in these countries. As energy-resources in households, wood charcoal is highly appreciated in urban areas while in rural areas, fire wood dominates. Indeed, charcoal presents a high calorific value of about 31.8 $\mathrm{MJ} / \mathrm{kg}$ against $16 \mathrm{MJ} / \mathrm{kg}$ for fire wood (Felix et al. 2011) and his storage is easier than woods.

The carbonization techniques used in developing countries to produce charcoal are still mostly traditional with low yields. The charcoal yield at atmospheric pressure seldom is low in general but industrial charcoal production under controlled pressure and temperature gives yields well over $40 \%$ (Eric et al. 2014). Although, high technological level controlled pressure carbonization systems are suitable for charcoal production, they are out of reach in the majority of developing countries because of their high cost associated to the lack of qualified labour.

Then, the widespread use of fire wood or charcoal as energy sources in households and industrial areas has led to environment degradation such as deforestation. So, in many West African countries such as Republic of Togo, the rate of deforestation is high. To mitigate this situation, it's therefore necessary to develop means of safety exploitation of the forest for energy purpose. Two processes can be used for this: the dissemination of improved carbonization systems/stoves and the utilization

\footnotetext{
* Corresponding author: kongnine@gmail.com
} 
of alternative fuels as biochar (Damgou et al. 2018a; Abdu et al. 2014). For example, as a part of its Energy policy, Togo plans to increase the dissemination of improved stoves and charcoal kilns utilization in households (Energy for All, Togo, 2012). But little emphasis had been placed in alternative energy fuels.

However many agricultural wastes such as coconut hulls are badly managed and polluted the markets vicinity of some coastal developing countries cities (Kouassi et al. 2016). Togo agricultural production generated 1715.81 thousand tons of residues per year (Koffi, 2001). These wastes, especially coconuts husks or shells are a source of diseases such as malaria and cholera. Some of these residues such as palm hulls, cockles of cashew seeds, coconut husks and shells, palmyra shells, are burned to free place leading to environmental pollution and non-valorization of the released energy.

One of the ways to improve the value of these agricultural by-products is to make their carbonization followed-up of the agglomeration of the obtained charcoal (biochar) by means-of binders using various techniques in order to produce a dense energy fuels (Pali et al. 2019; Akintaroa et al. 2017; Davies et al. 2013).

The aim of this study is to evaluate the potential of some local agricultural wastes in energy generation. Four residues such as coconut shells (Cocos Nucifera Linnaeus), palmyra shells (Borassus Aethiopum Mart), doum palm shells (Hyphaene Thebaica) and whole fruit of doum palm were studied in order to determine their carbonization conditions, first stage of their valorization as alternatives energies. Teak wood (Tectona Grandis) charcoal was used as control. Some of its characteristics had been derived from our results but others characteristics (see Table 3) were took from literature. Also, some of their combustion properties were evaluated. The scope of this work included the determination of thermal profile during the carbonization process, the charcoal yield, the moisture content, the bulk density, the lower calorific value and the ash minerals content such as chloride and sulfide.

\section{Materials and Methods}

\subsection{Samples collection}

All tested raw wastes used in this work were collected in the Republic of Togo (West Africa). Coconut shells were collected from small oil mills in Hahotoe (Lomé). The remains of palmyra nuts were collected from farmers in the Savannah region (Dapaong) after germination of seeds and / or fruits. The samples of the doum palm fruits were obtained from Kara city and its surroundings. Two kinds of palm doum were collected. The first one was the remains ripe fruit after succulent pulp extraction and the second one, the ripe fruit which dried on the palm trees. The teak wood was collected from Lomé city and were used as control. In the Figure 1, were presented photographs of different raw biomasses used in the present study.

\subsection{Samples preparation}

After collection, raw biomasses samples were stored separately. To ensure better drying and to reduce the proportion of void in the carbonizer, in order to optimize carbonization, the coconut shells and palmyra shells were manually crushed. Doum fruits without pulp and those with pulp were treated separately. Then, all the biomasses were sun-dried to a constant mass

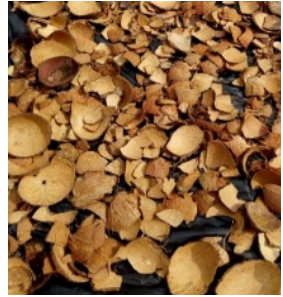

(a)

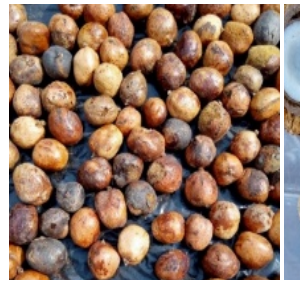

(d)

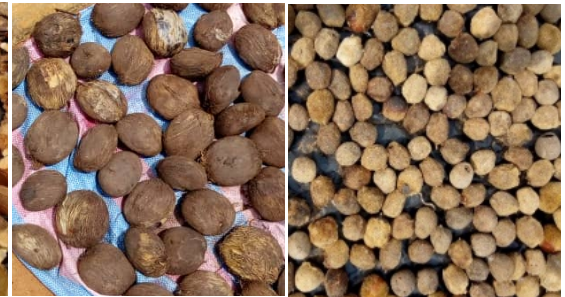

(b)
Fig. 1 Photographs of raw biomasses samples ; (a) Coconut Shells (CS) ; (b) Palmyra Shells (PS) ; (c) Doum Palm Shells (DPS) ; (d) Whole Fruits of Doum Palm (WFDP) ; (e) Doum palm fruit internal appearance ; (f) Teak Wood (TW)

\subsection{Carbonization furnace}

The biomasses used in the present study were carbonized separately in a cylindrical metallic charcoal stove made in Laboratory described elsewhere (Damgou et al. 2018b). Depending on the type of biomass, the stove may contain an average mass of $2900 \mathrm{~g}, 1600 \mathrm{~g}, 3500 \mathrm{~g}, 3500 \mathrm{~g}$ and $2300 \mathrm{~g}$ respectively for coconut shells, palmyra nuts shells, doum palm shells, whole fruit of doum palm and teak wood for the same occupied volume.

\subsection{Biomass characterization}

\subsubsection{Moisture content of the raw biomasses}

Before carbonization, some raw biomasses samples were first crushed into small sizes ranging from 0.3 to $1.5 \mathrm{~cm}$. Then, $20 \mathrm{~g}$ of each raw biomass sample were carefully weighed, introduced in a ceramic crucible and placed into the furnace sets at $105^{\circ} \mathrm{C}$ for 24 hours.

The moisture content was determined using the following formula:

$\mathrm{H}_{\text {biomasse }}=\frac{\mathrm{m}_{1}-\mathrm{m}_{2}}{\mathrm{~m}_{1}-\mathrm{m}_{0}} \times \mathbf{1 0 0}$

where:

- $\mathrm{m}_{0}$ is the mass of the empty crucible;

- $\mathrm{m}_{1}$ is the mass of the sample with crucible before drying;

- $\mathrm{m}_{2}$ is the mass of the sample and crucible after drying

\subsubsection{Carbonization process and thermal profile} measurement

Dried biomasses were took directly from the sun to the carbonizer. To determine the quantity of biomass to 
carbonize, the carbonizer was previously fulfilled with the biomass before emptied and the biomass weighed. Then, it was reintroduced into the carbonizer for carbonization. The carbonizer thus filled is placed on a tripod designed for this purpose. After closing all the lateral orifices with plugs made with small green woods, the carbonizer was covered.

At a height of $5 \mathrm{~cm}$ from one bottom orifice, a K-type thermocouple was introduced and connected to a digital display acquisition station. The introduced thermocouple allowed us to follow the evolution of the temperature, which was controlled by the plugs introduced into stove orifices, throughout the term of the carbonization process. This leads to thermal profile establishment, recorded as a function of time. The details of the dispositif of measurements is described eslsewhere (Damgou et al. 2018b).

\subsubsection{Charcoal yield}

The obtained charcoal yield was calculated using the following formula:

$\mathbf{r}=\frac{\mathbf{m}_{\mathrm{char}}}{\mathbf{m}_{0}-\mathbf{m}_{\mathrm{nc}}} \times \mathbf{1 0 0}$

where :

- $\mathrm{m}_{\mathrm{char}}$ is the mass of the obtained biochar

- $\mathrm{m}_{0}$ is the mass of raw biomass (sun dried)

- $\mathrm{m}_{\mathrm{nc}}$ is the mass of non-carbonized biomass at the end of the carbonization process

\subsubsection{Determination of the lower calorific value}

The lower calorific value of the studied biochars was determined using adiabatic oxygen bomb calorimeter (PARR Calorimeter, model 1241) in accordance with the French standard NF MO3-005 / EN 14918 / ISO 1928.

\subsubsection{Biochar moisture content}

To obtain moisture content, the biomass charcoals were crushed and sieved into a fine powder. The moisture content of the different biochars was estimated according to the European standard of reference EN 14774-1 described below :

$1 \mathrm{~g} \pm 0.1 \mathrm{~g}$ of the powder of each biochar was oven-dried at $105{ }^{\circ} \mathrm{C}$ until the mass variation is less than $0.1 \mathrm{~g}$. The test was repeated twice. Then the raw moisture, $\mathbf{H}_{\text {char }}$, content is determined as shown below:

$H_{\text {char }}=\frac{\mathbf{m}_{2}-\mathbf{m}_{3}}{\mathbf{m}_{2}-\mathbf{m}_{1}} \times \mathbf{1 0 0}$

- $\mathrm{m}_{1}$ is the mass of the empty crucible;

- $\quad \mathrm{m}_{2}$ is the sample and crucible mass before drying;

- $\mathrm{m}_{3}$ is the sample and crucible mass after drying

\subsubsection{Ash content determination}

Charcoal of each biomass was ground into powder in an aluminium mortar, before poured in a porcelain crucible and introduced into a desiccator, at $105^{\circ} \mathrm{C}$, for 12 hours. For each dry sample, $2 \mathrm{~g}$ were taken and placed in preweighed porcelain crucible before being introduced into a preheated muffle furnace set at $600^{\circ} \mathrm{C}$ for 1 hour, for calcination (Hiroki et al. 2013; Christian, 2016). After calcination, the crucible and its content were took out of the furnace at $105^{\circ} \mathrm{C}$ and reweighed. The new weight was recorded and the Ash Content AC (\%) was calculated using the following formula:

$\mathrm{AC}=\frac{\mathrm{m}_{\mathrm{ash}}}{\mathrm{m}_{\mathrm{char}}} \times \mathbf{1 0 0}$

- $\mathrm{m}_{\mathrm{ash}}$ is the mass of the ash just after calcination,

- $\mathrm{m}_{\text {char }}$ is the mass of the biochar powder after drying

\subsubsection{Bulk density measurement}

A weight of $10 \mathrm{~g}$ of each biochar powder was put in an uncovered porcelain crucible and introduced into a desiccator at $105^{\circ} \mathrm{C}$, for 12 hours and; after drying, they were immediately poured into a $250 \mathrm{~mL} \pm 1 \mathrm{~mL}$ graduated cylinder. Once their volume $\mathbf{V}_{\mathbf{0}}$ is known, the charcoal powder density was determined with the following formula:

$\boldsymbol{\rho}=\frac{\mathbf{m}_{\text {char }}}{\mathbf{V}_{0}}$

where:

- $\mathrm{m}_{\text {char }}$ is the mass of biochar powder after drying

- $\mathrm{V}_{0}$ is the volume of dried biochar powder

\subsubsection{Determination of electrical conductivity and ash} mineral content

The electrical conductivity of the ash solution and mineral salt content were determined with WTW cond.730 and volumetric titration (Damgou et al. 2018b).

\section{Results and discussion}

Table 1 presents the moisture content of the raw biomasses used in this work.

Table 1

Moisture content of the raw biomasses in weight percentage

\begin{tabular}{ccccrc}
\hline Biomass & PS & CS & DPS & WFDP & TW \\
\hline Moisture (\%) & 7.82 & 8.11 & 9.48 & 14.28 & 11.11 \\
\hline
\end{tabular}

As showed in Table 1, palmyra shells presented the lower moisture content ( $7.82 \%)$, followed by coconut shells (8.11 \%). Similar results were reported by Christian (Christian et al. 2016). The highest moisture content $(14.25 \%)$ was recorded for whole fruit of doum palm. The high value of moisture content could be due to the presence of pulp and albumen in the fruit. The moisture content of $11.11 \%$ was obtained for teak wood used as control.

Figure 2 presents the temperature profile at the bottom of the biomass charcoal stove, during carbonization progress of each biomass sample. The temperature is plotted as a function of time. One of the fundamental parameters which determines the performance of a charcoal furnace and the charcoal obtained quality is temperature evolution in the carbonizer during the carbonization process. Few minutes after samples 
inflammation, and for each biomass, temperature increases to a maximum value noted $\mathrm{T}_{\max }$ and decreases to a minimum value noted $\mathrm{T}_{\min }$, then regrows significantly, as is shown the Figure 2 in which, for clarity, $\mathrm{T}_{\max }$ and $\mathrm{T}_{\min }$ are represented only for coconuts shells. However, their growth rates were not similar.

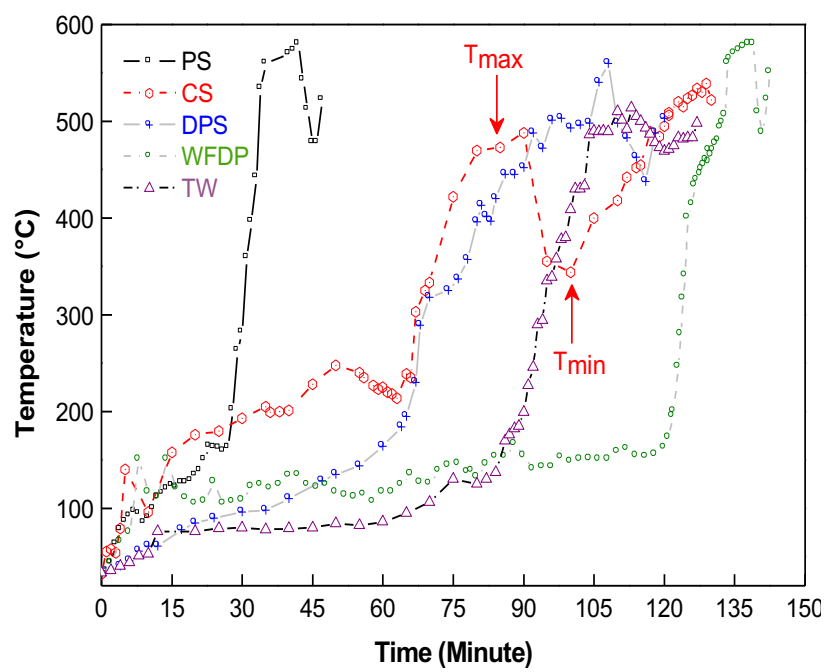

Fig. 2 Evolution of the temperature at the bottom of the furnace during carbonization process

During the first phase the temperature increases slightly. However, the length of this phase depends on the type of biomass. The results showed that this length is 27 , 62, 62, 85 and 120 min respectively for palmyra shells (PS), coconut shells (CS), doum palm shells (DPS), teak wood (TW) and whole fruit of doum palm (WFDP). This phase corresponds to biomass dehydration where physical bound water is released in the form of vapor as well as oxygenated gases such as carbon monoxide (CO), carbon dioxide $\left(\mathrm{CO}_{2}\right)$, acetic acid $\left(\mathrm{CH}_{3} \mathrm{COOH}\right)$ and methanol $\left(\mathrm{CH}_{3} \mathrm{OH}\right)$ from decaying of the least stable constituents of biomass. The colour of this gas is white. (Patrick 2007). This could explain the fact that the WFDP and TW biomasses which present the highest moisture content have the longest dehydration phase.

The second phase corresponds to a high increase in temperature almost linearly to its maximum value, noted $\mathrm{T}_{\max }$. At this stage, an exothermic reaction occurs. The thermal increase can be due to the emission of gases such as hydrogen $\left(\mathrm{H}_{2}\right)$, methane $\left(\mathrm{CH}_{4}\right)$, carbon monoxide $(\mathrm{CO})$, carbon dioxide $\left(\mathrm{CO}_{2}\right)$ and volatile matter. The progression of the carbonization zone increases the heat locally, as the thermochemical reactions of pyrolysis and gasification took place (Damgou et al. 2018b; Hiroki et al. 2013; Hussein et al. 2015). The temperature drops from $\mathrm{T}_{\max }$ to $\mathrm{T}_{\min }$ and at the end of this period, the carbonization process is completed. The minimum temperature achieved corresponds to the end of the carbonization process. The second increase of the furnace temperature is due to the obtained charcoal consumption. Practically the end of the carbonization process is marked by the appearance of exhaust gases less dense and blue coloured. Thus, few minutes after $\mathrm{T}_{\min }$ reached, the charcoal obtained must be transferred into a closed container to prevent its combustion.

The PS biomass residential time was the lowest; its carbonization process ended before 60 minutes. This lowest residential time can be explained by their lower moisture content and their advanced state of degradation due to the fact that they have been residing for a moment in the soil. Indeed, it should be noted that these shells were obtained after germination of the fruit nut.

In Table 2 are presented the maximum, $\mathrm{T}_{\max }$, and minimum temperatures, $\mathrm{T}_{\min }$, residence time $(\mathrm{RT})$, biochar yield (BY). The biochar of CS, PS, DPS, WFDP and TW were produced during slow pyrolysis. As shown in Table 2, their maximum temperature was lower than $700{ }^{\circ} \mathrm{C}$ (Hussein et al. 2015). WFDP presented the highest residence time and the lowest one was recorded for PS biomass. Due to their lower moisture content and their advanced state of degradation, the PS biomass carbonized very quickly, leading to a high maximum temperature and a low residence time (Junna et al. 2017). Corn cobs also showed a relatively similar reaction (Damgou et al. 2018b). The results showed that the charcoal yield average ranged from $27.57 \%$ (for WFDP) to $37.81 \%$ (for PS). A yield of $28.80 \%$ was recorded for teak wood at maximum temperature of $501{ }^{\circ} \mathrm{C}$. This achieved yield was almost two times higher than $15 \%$ obtained by (Coulibaly et al. 2012) for the same specie (teak wood). This result proved the efficiency of the furnace and the method used to produce the biomass charcoal in the present work.

During the carbonization process, the maximum yield (42.32\%) was obtained for palmyra shells at the final maximum temperature of $280{ }^{\circ} \mathrm{C}$. This value was almost equal to (43\%) obtained at $467{ }^{\circ} \mathrm{C}$ by Damgou (Damgou et al. 2018b) with the palm kernel husks using the same carbonization furnace. The slight difference could be due to the carbonization temperature associated to the difference in the organic nature of these two biomasses.

Figure 3 presents the effect of maximum temperature on the charcoal yield. For each biomass, the biochar mass yield decreases when increasing maximum temperature. The lowest yield (24.42 \%) was reported at highest maximum temperature recorded $\left(590{ }^{\circ} \mathrm{C}\right)$ for doum palm shells (Junna et al. 2017). Exceptionally, for teak wook, only one experiment has been done due to some technical problem. This is why, its graph is not plotted in Figure 3.

As shown in Figure 3, the biomass charcoal mass yield dropped significantly for all biomasses as the final maximum temperature increased. For example, charcoal yield dropped more than $13 \%$ for whole fruits of the doum palm when final temperature increases from $438{ }^{\circ} \mathrm{C}$ to $580^{\circ} \mathrm{C}$. This phenomenon could be due to volatile matter evaporation or the combustion of the obtained charcoal. Similar observations were made by (Jean-Philippe et al. 2012) during energy valorization of cashew nuts and by Kuihua (Kuihua et al. 2016) when studying the segmented carbonization of corn straw and cotton stems. The charcoal yield of WFDP and PS biomasses were respectively $25.08 \%$ and $31.57 \%$ for the same maximum temperature $\left(580^{\circ} \mathrm{C}\right)$ reached. This result indicated that charcoal yield depends not only on the maximum temperature but also on the type of the biomass involved. The charcoal physico-chemical parameters influenced the energy quality of the derived fuel. The moisture content of charcoals depends on the type of biomass and the atmospheric conditions. 
Table 2

Values of $\mathrm{T}_{\max }, \mathrm{T}_{\min }$ and the residence time (RT), biomass charcoal yield (BY)

\begin{tabular}{cccccc}
\hline Biomass & $\mathbf{T}_{\max }\left({ }^{\mathbf{}} \mathbf{C}\right)$ & $\mathbf{T}_{\min }\left({ }^{\circ} \mathbf{C}\right)$ & $\begin{array}{c}\mathbf{R T} \\
(\mathbf{m i n})\end{array}$ & BY (\%) & Average Yield (\%) \\
\hline \multirow{2}{*}{ CS } & 539 & 344 & 88 & 28.84 & \\
& 501 & 488 & 100 & 29.34 & 30.31 \\
& 314 & 268 & 150 & 32.98 & \\
PS & 580 & 478 & 45 & 31.57 & 37.81 \\
& 450 & 319 & 49 & 37.32 & \\
DPS & 280 & 136 & 57 & 42.32 & 27.57 \\
& 590 & 406 & 92 & 24.42 & \\
WFDP & 560 & 438 & 118 & 30.57 & 32.86 \\
& 580 & 488 & 142 & 25.08 & 28.80 \\
\hline
\end{tabular}

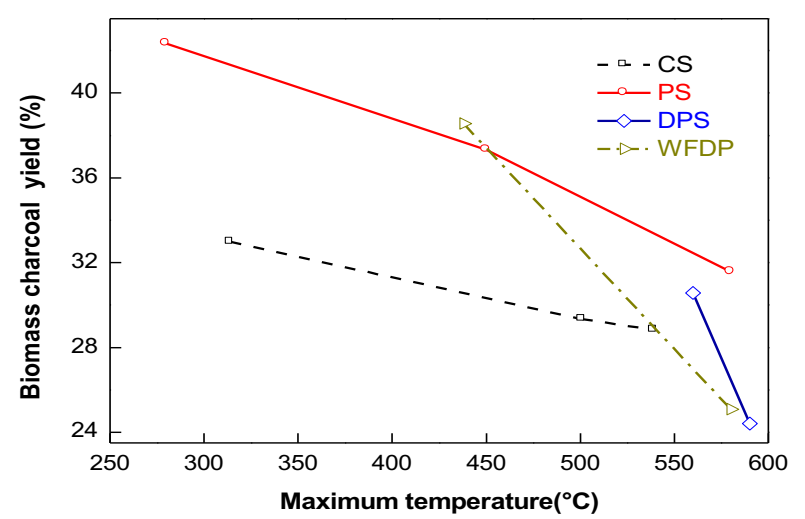

Fig. 3 Influence of maximum temperature $\left(\mathrm{T}_{\max }\right)$ on biomass charcoal yield

Table 3 summarized the moisture content and ash content of the produced biochar. Among the four biomass charcoals studied, PS showed the highest moisture content (5.24\%) followed by CS (4.55\%), DPS (4.52\%) and WFDP (4.22\%). According to our results TW charcoal had the lowest moisture content $(4.01 \%)$ but in literature we have used it is $5.3 \%$. These results indicate that the produced charcoals are able to meet the standard for good commercial fuel. The moisture content depends on the environment relative humidity and the biochar porosity. According to Ananias Francisco D. J. (Ananias et al. 2016) the more humid the environment as well as charcoal porosity the greater the absorption of moisture by charcoal. The moisture content decreased from the raw biomass to the obtained charcoal due to the fact that carbonization reduced the moisture content (Yerizam et al. 2013).

Table 3 summarizes the lower calorific value (LCV), moisture content (MC), bulk density (BD), ash content (AC) and heat per volume unit (HPVU) of the analyzed charcoals samples. The coconut shells charcoal presented the highest LCV (28.059 MJ.kg-1). The LCV of doum palm shells and palmyra shells were respectively $26.929 \mathrm{MJ} . \mathrm{kg}$ 1 and 26.111 MJ.kg-1. The lowest value of LCV (25.864 MJ.kg-1) was recorded for whole fruits of doum palm biomass charcoal probably related to their chemical (mineral and organic) constituents. Compared to the results of Damgou (Damgou et al. 2018b), all biochars have higher LCV than palm kernel shells (25.095 MJ.kg-1), corn cobs (24.760 MJ.kg-1) and green coconut husks (16.560 MJ.kg-1). The carbonization increases the carbon concentration of organic material as well as calorific value. For example, palmyra shells biomass calorific value (20.18 $\mathrm{MJ} / \mathrm{kg}$ ) reported by Y. Demirel (Demirel, 2012) was found to be lower than its charcoal LCV recorded in the present work. The same LCV result was obtained for coconut shells $(21.17 \mathrm{MJ} / \mathrm{kg})$ by S.S. Abdullah and S. Yusup (Abdullah et al. 2010) versus $28.059 \mathrm{MJ.kg}^{-1}$ for its biochar. As shown in table 3, ash content (AC) ranged from $2.90 \%$ for teak wood charcoal to $18.75 \%$ for those of whole fruits of doum palm. These outcomes are entirely consistent with the fact that wood charcoal ash content ranged between $0.5 \%$ and $5 \%$, while charcoal from agricultural residues showed higher ash content values (Christian et al. 2016; Demirbas 2004). According to our results, TW charcoal presented the lowest ash content $(3.74 \%)$, the highest one was recorded for whole fruits of doum palm $18.75 \%$. This result could be due to the presence of albumen in whole fruits which contains a high level of inorganic matter. In fact, many studies reported that high mineral content in biomass has a negative impact on its calorific value by lowering it (Demirbas 2008; Duruaku et al. 2016; Hanisom et al. 2010). The lowest heat value recorded for whole fruit of doum palm can then be explained by its highest ash content.

Bulk density is an important parameter for determining energy per volume unit. For given fuel the burning time increases with density (Mitchual et al. 2014). The results showed that coconut shells presented the highest density $\left(0.625 \mathrm{~g} / \mathrm{cm}^{3}\right)$, followed by palmyra shells $\left(0.492 \mathrm{~g} / \mathrm{cm}^{3}\right)$, whole fruit of doum palm $\left(0.442 \mathrm{~g} / \mathrm{cm}^{3}\right)$ and doum palm shells $\left(0.415 \mathrm{~g} / \mathrm{cm}^{3}\right)$. The lowest value was recorded for teak wood charcoal $\left(0.282 \mathrm{~g} / \mathrm{cm}^{3}\right)$. The highest energy per volume unit were respectively $17536.88 \mathrm{~J} / \mathrm{cm}^{3}$, $12846.61 \mathrm{~J} / \mathrm{cm}^{3}$ recorded for coconut shells and palmyra shells charcoals. With $13830.09 \mathrm{~J} / \mathrm{cm}^{3}$, teak wood had the second highest energy per volume unit after that of coconut shells. These results make coconut and palmyra shells charcoals promising candidates for use as alternative fuels to wood charcoal in households. It can be seen from table 3 that coconut shells charcoal energy per volume unit was higher than those of teak wood charcoal. This could explain the fact that some households do not like to use charcoal from teak wood for cooking because it burns quickly. 
Citation: Kongnine, D.M., Kpelou, P., Attah, N., Kombate, S., Mouzou, E., Djeteli, G. and Napo, K. (2020) Energy Resource of Charcoals Derived from Some Tropical Fruits Nuts Shells. Int. Journal of Renewable Energy Development, 9(1), 29-35, doi.org/10.14710/ijred.9.1.29-35

$\mathrm{P}$ a g e 134

Table 3

Low calorific value (LCV), high calorific value (HCV), moisture content (MC), ash content (AC), bulk density (BD) and heat per volume unit (HPVU) of different biochars samples and teak wood charcoal.

\begin{tabular}{c|cccccc}
\hline \multicolumn{1}{c}{ Biochar } & LCV (MJ.kg-1) & HCV (MJ.kg-1) & MC (\%) & AC (\%) & BD (g/cm $\left.{ }^{3}\right)$ & HPVU (J/cm $\left.{ }^{3}\right)$ \\
\hline CS & 28.059 & 28.622 & 4.55 & 4.09 & 0.625 & 17536.88 \\
PS & 26.111 & 26.691 & 5.24 & 6.87 & 0.492 & 12846.61 \\
DPS & 26.929 & 26.691 & 4.52 & 8.42 & 0.415 & 11175.54 \\
WFDP & 25.864 & 26.419 & 4.22 & 18.75 & 0.442 & 11431.89 \\
TW (Data from & 32.163 & - & 5.3 & 2.90 & 0.430 & 13830.09 \\
Lena et al. 2017$)$ & & & & & \\
\hline
\end{tabular}

Table 4 presents the $\mathrm{pH}$ and electrical conductivity of ash solution for the biomasses charcoals studied. The extracted ash $\mathrm{pH}$ values ranged from 10.62 (for TW) to 11.24 (for CS). Similar $\mathrm{pH}$ range was reported for rice husks and for some trees (Coulibaly et al. 2006; Hanisom et al. 2010). This alkaline $\mathrm{pH}$ values suggest that these charcoals can be also used to reduce soil acidity. Indeed, according to their chemical and physical characteristics, biochar could be used either as alternative fuels or soil amendment (Agrafioti et al. 2013).

Table 4

$\mathrm{pH}$ and electrical conductivity of ash solution

\begin{tabular}{|c|c|c|}
\hline Biochar & $\mathbf{p H}$ & $\begin{array}{l}\text { Electrical Conductivity } \\
(\mu \mathrm{S} / \mathrm{cm})\end{array}$ \\
\hline PS & 11.24 & 3048 \\
\hline WFDP & 11.21 & 3376 \\
\hline $\mathrm{CS}$ & 11.19 & 2061 \\
\hline DPS & 10.82 & 1835 \\
\hline TW & 10.65 & 1563 \\
\hline
\end{tabular}

The studied biomass charcoals ash mineral content was reported in Table 5. Teak wood, palmyra shells and coconut shells charcoals ash showed lowest sulfide and chloride contents indicating that they are not harmful for cooking. Otherwise, whole fruits of doum palm and doum palm shell presented high chloride $(9.73 \%)$ and sulfide $(1.75 \%)$ contents. It is generally known that sulfur and chlorine compounds are toxic and harmful to health and environment. Then it is essential to take precautions if these charcoals are used as fuel.

Table 5

Mineral content of the studied charcoals ash

\begin{tabular}{c|cccc}
\hline Biochar & $\begin{array}{c}\mathrm{Cl} \\
(\mathrm{g} / 100 \mathrm{~g})\end{array}$ & $\begin{array}{c}\mathrm{S} \\
(\mathrm{g} / 100 \mathrm{~g})\end{array}$ & $\begin{array}{c}\mathrm{K} \\
(\mathrm{g} / 100 \mathrm{~g})\end{array}$ & $\begin{array}{c}\mathrm{Na} \\
(\mathrm{g} / 100 \mathrm{~g})\end{array}$ \\
\hline CS & 2.42 & 0.46 & 10.80 & 2.40 \\
PS & 0.95 & 0.79 & 13.70 & 0.80 \\
DPS & 3.50 & 1.34 & 11.70 & 0.16 \\
WFDP & 9.73 & 1.75 & 14.80 & 0.10 \\
TW & 0.76 & 0.28 & 7.24 & 0.20 \\
\hline
\end{tabular}

\section{Conclusion}

This work focused on the energy potential of four biochar from agricultural residues which are coconut shells, palmyra shells, whole fruit of doum palm and doum palm shells. Teak wood charcoal was used as control.
The first step was to evaluate the charcoal yield after each biomass carbonization. The second step was to evaluate some energy parameters of the obtained biomasses charcoals.

From the obtained results, it can be seen that all the average biomasses charcoals yield except doum palm shell one's, were higher than that of the teak wood which has the highest LCV, followed respectively by those from coconut shells, doum palm shells and whole fruit of doum palm biochar. But the coconut shells biochar, denser, has the highest energy per volume unit.

Among the five charcoals, only whole fruit of doum palm ash contained higher chloride and sulfide which compounds are known to be toxic and harmful for health and environment.

In view of these results, all the obtained charcoals can be used as potential alternative fuel to wood charcoal. However, precautions may be taken when the whole fruit of doum palm is used as alternative fuel. Further works and investigations are needed to be performed in order to understand the mechanisms involved in the carbonizer maximum temperature control and how to enhance the energy properties of the produced biochar.

\section{References}

Abdu, Z. \& Sadiq, A. G. (2014) Production and Characterization of Briquette Charcoal by Carbonization of Agro-Waste. Energy and Power, 4 (2), 41-47.

Abdullah, S.S. \& Yusup, S. (2010) Method for Screening of Malaysian Biomass Based on Aggregated Matrix for Hydrogen Production through Gasification. J. App. Sci. 10 (24), 3301-3306.

Agrafioti, E. Bouras, G. Kalderis D. \& Diamadopoulos E. (2013) Biochar production by sewage sludge pyrolysis, Journal of Analytical and Applied Pyrolysis, 101, 72-78.

Akintaroa, A.O., Musa, A.I., Ajobo, J.A. \& Oyewusi, T.F. (2017) The Potentials of Using Carbonized Corncob to Produced Briquettes as an Alternative to Fuelwood. FUTA Journal of Research in Sciences, 13, 137-145.

Ananias, F. D. J. Lucas, P. P. Saly, T. Artur, Q. L. \& José, O. B. A. M. de Andrade (2016) Higroscopicity of charcoal produced in different temperatures. CERNE, 22 (4), 423-430.

Christian, R. L. Hassan, M. R. Daniel, J. S. \& Christian, Z. (2016) Char fuel production in developing countries-A review of urban biowaste carbonization. Renewable and Sustainable Energy Renews 59, 1514-1530.

Coulibaly, B.\& Jocelyn, L. (2006) Expérimentation de production de charbon de bois commercial à partir des produits d'éclairies des plantations de teck dans la forêt de TENE. Séminaire FORAFRI de Libreville-session 3 : produit de forêt.

Damgou, M. K. Pali, K. Komi, S. \& Kossi N. (2018) Evaluation of Some Combustion Characteristics of Biochar produced from Coconut Husks, Corn Cobs and Palm Kernel Shells, 
International Journal of Innovation and Applied Studies, 24 (3), 1124-1130.

Damgou, M. K. Pali, K. Mazabalo B. \& Kossi N. (2018) Calorific value enhancement due to combination of biochars from corn cobs, tender coconut husks and palm ker-nel shells. Int. J. Adv. Res., 6(11), 234-238.

Davies, R.M. \& Davies, O. A. (2013) Physical and Combustion Characteristics of Briquettes Made from Water Hyacinth and Phytoplankton Scum as Binder. Journal of Combustion, https://doi.org/10.1155/2013/549894

Demirbas, A. (2008) Biodiesel : A Realistic Fuel Alternative for Diesel Engines. Springer, London, 21-22.

Demirbas, A. (2004) Effect of temperature and particle size on biochar yield from pyrolysis of agricultural residues. Journal Analytical and Applied Pyrolysis 721, 243-248.

Demirel, Y. (2012) Energy, energy types, in Green Energy, Technology. Springer-Verlag, London.

Duruaku, J. I. Ajiwe, V.I.E. Okoye, N.H. \& Arinze, R.U. (2016) An Evaluation of the Calorific Values of the branches and Stems of 11 Tropical Trees. Journal of Sustainable Bioenergy Systems, 6, 44-54.

Eric, S. N. Joel, B. Patrick, R. Jeremy, V. \& Laurent, V. D. S. (2014) Optimisation de la réactivité des charbons végétaux pour la réduction du minerai de fer en haut fourneau, Congrès international sur les matériaux et l'énergie cimaten, Sousse, Tunisie, 14-16.

Évaluation rapide et analyse des Gaps; énergie durable pour tous, Energy For All, Jui. 2012. https://www.se4allafrica.org/fileadmin/uploads/se4all/Documents/Country_RAGAs/TO GO RAGA FR Released.pdf, Access on 13 July 2019

Felix, M. \& Gheewala, S. H. A. (2011) Review of biomass energy dependency in Tanzania. Proceeding sof the 9th eco-energy and materials science and engineering symposium. Energy Procedia, 9, 338-343.

Hanisom, A. Kun, A. M. \& Hongwei, W. (2010) Biochar as fuel : 2. Significant Differences in Fuel Quality and Ash Properties of Biochars from Various Biomass Components of Mallee Trees. Energy Fuels, 24, 1972-1979.

Hiroki, H. Hirroomi \& Yusrizal, M. I. (2013) Wood Pyrolysis in Pre-Vacuum Chamber. Journal of Sustainable Bioenergy Systems, 3, 243-249.

Hussein, K N, Sarah, E. H., Gerard, C. \& Robert, T. B. (2015) Sustainable Technologies for Small-Scale Biochar Production-A Review. Journal of Sustainable Bioenergy Systems, 5, 10-31.

Jean-Philippe, T. \& Pascale, N. (2012) Caractérisation et traitement thermochimique des coques d'anacarde en vue de leur valorisation énergétique dans les procédés de transformation artisanale de noix de cajou. Déchets sciences et techniques - revue francophone d'écologie industrielle, 62, 28-35.

Junna, S. Fuhong, H., Yinghua, P. \& Zhenhua, Z. (2017) Effects of pyrolysis temperature and residence time on physicochemical properties of different biochar types, Acta agriculturae scandinavica, section B-soil \& Plant science, 67 (1), http://dx.doi.org/10.1080/09064710.2016.1214745, $12-22$.

Koffi, S. (2001) Rapport d'étude sur les données du bois-énergie au Togo, http://www.fao.org/3/a-x6801f.pdf., Access on 13 July 2019

Kouassi, S. G. Grah, P. A. Bini, K. D. Patrick, D. Didier, R. Drissa, O. K. Séraphin, K. Ghislaine, G. M. D. B. \& Albert, T. (2016) Contribution à l'étude de quatre charbons activés à partir des coques de noix de coco. Afrique science, 5 (12), 229-245.

Kuihua, H. Qian, W. Jianli, Z. Luo, K. H. Hui, L. Yang, C. \& Chunmei, L. (2016) Combustion pattern, characteristics, and kinetics of biomass and chars from segmented heating carbonization : Combustion Patterns and kinetics. Asia-Pac. J. Chem. Eng., 11, 812-822.

Lena, D. M. Kenneth, L. B. \& Francis, K. (2017) Experimental analysis of three common tree species in Ghana. International Journal of Engineering Sciences \& Research Technology, 6 (6), 133-141.

Mitchual, S. J. Frimpong-Mensah, K. \& Darkwa, N. A. (2014) Evaluation of Fuel Properties of Six Tropical Hard-wood Timber Species for Briquettes. Journal of Sustainable Bioenergy Systems, 4, 1-9.

Pali, K. Damgou, M. K. Saboilliè, K. Essowè, M. \& Kossi, N. (2019) Energy Efficiency of Briquettes Derived from Three Agricultural Waste's Charcoal Using Two Organic Binders. Journal of Sustainable Bioenergy Systems, 9, 79-89. https://doi.org/10.4236/jsbs.2019.92006

Patrick, D. E. M. (2007) Etude de faisabilité d'une unité de production de charbon vert, Projet de fin d'études en vue de l'obtention du diplôme de l'ingénieur de conception, Page 4 .

Yerizam, M. Marsi, M. \& Novia, N. (2013). Characteristics of Composite Rice Straw and Coconut Shell as Biomass Energy Resources (Briquette). International Journal on Advanced Science, Engineering and Information Technology , 3 (3), 42-48. 